\title{
Wzory europejskie a muzułmańska tradycja polityczna Hayr ad-Dīn at-Tūnusī (1822-1890)
}

B adając genezę i rozwój myśli reformatorskiej w świecie arabsko-muzułmańskim ${ }^{1}$ zauważamy dwa mechanizmy, które doprowadziły do ukształtowania się tejże myśli. Z jednej strony tendencje modernistyczne, które były wynikiem upadku i zastoju, implikujących dążenia

Życie i działalność reformatora omawiają szczegółowo dwie monografie w języku francuskim: G. S. Krieken, Khayr al-Din et la Tunisie (1850-1881), Leiden 1976 i M. Smida, Khereddine ministre reformateur, Tunis 1970 oraz opracowania arabskojęzyczne - S. Abū Hamdān, Hayr ad-Dīn at-Tūnusī, Bejrut 1993; A. Al-Hūsī, Hayr ad-Dīn at-Tūnusī - abū anNahḍa, Tunis 2004; M. Mazālī, Hayr ad-Dīn rağul ad-dawla, Tunis 1971; M. Aš-Šamlī, $\underline{H} a y r$ ad-Dīn Bāšā, Tunis 1973.

Na temat historii świata arabskiego patrz: J. Danecki, Arabowie, PIW, Warszawa 2001; M. Gdański, Arabski Wschód: Historia - gospodarka - polityka, KIW, Warszawa 1963; U. Haarmann (red.), Geschichte der arabischen Welt, Beck, Monachium 2001; Ph. Hitti, Dzieje Arabów, przekład W. Dembski, M. Skuratowicz, E. Szymański, PWN, Warszawa 1969; A. Hourani, Historia Arabów, przekład J. Danecki, Wyd. Marabut, Gdańsk 2002; B. Lewis, Arabowie w historii, przekład J. Danecki, PIW, Warszawa 1995; B. Lewis, Bliski Wschód, przekład K. Mierzęcki, Prószyński i S-ka, Warszawa 1998; B. Lewis, Islam in History. Ideas, People and Events in the Middle East, Oxford University Press, Londyn 1973; B. Lewis, Muzułmański Bliski Wschód, przekład J. Danecki, Wyd. Marabut, Gdańsk 2003; D. Madeyska, Historia świata arabskiego. Okres osmański 1516-1920, Wyd. Uniwersytetu Warszawskiego, Warszawa 1988; J. Zdanowski, Historia Arabii Wschodniej, Ossolineum, Wrocław 2008; J. Zdanowski, Historia Bliskiego wschodu w XX wieku, Ossolineum, Wrocław 2010. 
do odnowy i naprawy istniejącego stanu, a więc potrzeba reform wyrosła na gruncie przekonania o potrzebie zmian wobec świadomości niedoskonałości i chęci odzyskania minionej świetności, co doprowadziło do wykrystalizowania się ruchu określanego terminem iṣlāh - naprawa, dążącego do tağdīd - odnowy. Twórcy takich ruchów to Muhammad Ibn 'Abd al-Wahhāb², Walī Allāh ${ }^{3}$, Muhammad Ibn 'Abd Allāh aš-Šawkānī ${ }^{-4}$ i inni.

Zdrugiej zaśstrony-ideologie reformatorskie będące w dużym stopniuskutkiemkontaktówzcywilizacjąeuropejską, rodzącesiępodwpływem Zachodu, a przede wszystkim pod wpływem rozczarowania jego pozorną nowoczesnością cywilizacyjną, podzielone na dwa nurty - modernistyczny, z którego wyrosły nacjonalizmy lokalne i tendencje sekularystyczne ${ }^{5}$ oraz konserwatywny, nazywany klasycystycznym, który dał początek

2 Muhammad Ibn ‘Abd al-Wahhāb (1703/4-1792) - twórca ideologii religijnej nazywanej wahhabizmem, u którego podstaw legła doktryna radykalnego tawhīdu (jedynobóstwo). Głosił potrzebę odrodzenia koncepcji Boga jedynego poprzez oczyszczenie islamu z wszelkich nowinek i herezji - bid'a i powrót do najstarszych, fundamentalnych jego zasad. Główne dzieło to At-Tawhīd (Jedynobóstwo). Działał na terenie Półwyspu Arabskiego, ale stworzona przez niego ideologia fundamentalizmu wahhabickiego wywarła duży wpływ na ruchy religijne i polityczne w innych rejonach świata muzułmańskiego. Patrz: J. Danecki, Podstawowe wiadomości o islamie, Wydawnictwo Akademickie Dialog, Warszawa 2007, s. 421-426.

3 Walī Allāh (1703-1762) - postulował reformę religijną, filozoficzną i polityczną islamu, a podstawą jego działań reformatorskich był sufizm. Dążył do przywrócenia islamowi jego utraconej jedności (panislamizm). Postulując oparcie organizacji współczesnych państw islamu na klasycznych muzułmańskich teoriach politycznych, wypracował oryginalną koncepcję, którą scharakteryzował w Al-Budūral-bāziḡa (Wschodzące księ-

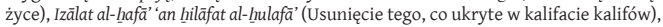
Huğğat Allāh al-bāliḡa fí asrār al-hiadīt wa-hukm at-tašrī (Wymowny argument Boga czyli tajniki hadisów i zasady prawodawstwa). Walī Allāh działał na terenie Indii, stał się wzorem dla wielu indyjskich ruchów reformatorskich. Patrz: J. Danecki, op. cit., s. $426-429$.

4 Muhammad Ibn 'Abd Allāh aš-Šawkānī (1759-1834) - dążył do odnowy islamu poprzez powrót do źródeł, czyli Koranu i sunny - tradycji Proroka. Swoje koncepcje w tym zakresie ujął w dziele Šarh aṣ-șudūr fi tahrīm raf al- qubūr (Radość serc czyli o zakazie wznoszenia grobowców). Działał na terenie Jemenu. Patrz: J. Danecki, op. cit., s. $429-430$.

5 Sekularyzm i nacjonalizm w świecie arabsko-muzułmańskim patrz: J. Danecki, op. cit., s. 509-523. 
fundamentalizmowi ${ }^{6}$. Przedstawiciele tych nurtów to: Rifā‘ aț-Ṭahțāwī $\overline{\mathbf{l}}^{7}$,

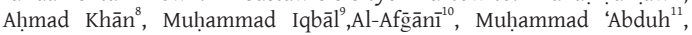

Fundamentalizm muzułmański patrz: J. Danecki, op. cit. s. 481-508; H. A. Jamsheer, Historia powstania islamu jako doktryny społeczno-politycznej, Wydawnictwo Akademickie Dialog, Warszawa 2009, s. 179-192; H. A. Jamsheer, Reforma władzy i spoleczeństwa $w$ arabsko-muzułmańskiej myśli politycznej wieków XIX $i$ XX, Ibidem, Łódź 2008, s. 124-138. Zagadnienie fundamentalizmu religijnego omawia $\mathrm{w}$ polskim piśmiennictwie m.in. K. Armstrong, W imię Boga. Funadamentalizm w judaizmie, chrześcijaństwie $i$ islamie, WAB, Warszawa 2005; B. Tibi, Fundamentalizm religijny, PIW, Warszawa 2001 i S. Bruce, Fundamentalizm, Wydawnictwo Sic!, Warszawa 2006.

7 Rifā'a aț -Ṭahțāwī (1801-1873) - nazywany twórcą modernizmu egipskiego, postulował konieczność wprowadzenia reform społecznych, gospodarczych i politycznych oraz reinterpretację šarĩa dla potrzeb współczesnego świata islamu. Rozwinął koncepcję patriotyzmu hubb al-wațan i teorię dziedziczenia kulturowego i odzyskiwania, zgodnie z którą zacofany Zachód ucywilizował się niegdyś dzięki wiedzy przejętej od Arabów i ta wiedza winna posłużyć odrodzeniu świata islamu. Tahlīs al-ibrīz fì talhịs barīz (Wydobycie czystego złota czyli krótki opis Paryża). Patrz: J. Danecki, op. cit., s. 433-434; H. A. Jamsheer, Historia powstania islamu..., s. 89-110, H. A. Jamsheer, Reforma władzy..., s. $13-36$.

8 Aḥmad Khān (1817-1898) - indyjski reformator i zwolennik nowocześności na wzór brytyjski, twórca nurtu nayčariyya (naturalizm) sięgającego do tradycji mutazylickiego racjonalizmu i idei zgodności rozumu i objawienia. Dążył do pogodzenia wartości islamu z kulturą europejską, swoje poglądy wspierał rozważaniami teologicznymi wskazującymi na podobieństwa pomiędzy islamem a chrześcijaństwem. Patrz: J. Danecki, op. cit., s. 436 i 442-443.

9 Muhammad Iqbāl (1877-1938) - wybitny myśliciel indyjski, działacz na rzecz obrony, odrodzenia i unowocześnienia islamu. Autor m.in. dzieła The Reconstruction of Religious Thought in Islam (Rekonstrukcja myśli religijnej w islamie) i Payām-i Mašriq (Posłannictwo Wschodu). Patrz: J. Danecki, op. cit., s. 443-446.

10 Ğamāl ad-Dīn Al-Afāānī (1838-1897) - uważany za twórcę idei panislamizmu. Jego myśl reformatorska była swoistym połączeniem modernizmu z tradycjonalizmem, ponieważ postulował konieczność wykorzystania wzorców europejskich w rozwijaniu islamu oraz odwołanie się do racjonalizmu muzułmańskiego (głównie mutazylizmu), a wysuwając koncepcję naśladowania Zachodu przez powrót do własnych wartości islamu znalazł się w nurcie salafickim (powrót do tradycji szlachetnych przodków as-salaf aș-șāliḥ). Główne dzieło to Ar-Radd 'alà ăd-dahriyyīn (Odpowiedź materialistom). Patrz: J. Danecki, op. cit. s. 449-45, H. A. Jamsheer, Historia powstania islamu..., s. 110-121; H. A. Jamsheer, Reforma władzy..., s. 37-49.

11 Muhammad 'Abduh (1849-1905) - najwybitniejszy przedstawiciel reformizmu arabskiego, uczeń i bliski współpracownik Ğamāla ad-Dīna Al-Af̄̄ānīego. Dążył do unowocześnienia świata arabskiego, islamu i Egiptu we współpracy z władzami, poprzez zharmonizowanie tradycji muzułmańskich z cywilizacyjnymi osiągnięciami europejskimi, w oparciu o przekonanie o racjonalizmie islamu, który stanowi podstawę dla aktywnej budowy nowoczesnej kultury. Swoje koncepcje w tym zakresie przedstawił w Risālat at-tawhīd (List o monoteizmie). Wyodrębnił z panislamizmu ideę panarabską, rozwijaną przez późniejszych myślicieli, zgodnie z którą na tożsamość Egipcjan składały się trzy elementy: narodowość egipska, kultura arabska i religia 
'Abd ar-Rahmān al-Kawākibị ${ }^{-12}$, Muhammad Rašīd Riḍà ${ }^{13}$, a także Hayr adDīn at-Tūnusî̀ ${ }^{-14}$.

Ich koncepcje reformatorskie pojawiły się w wieku XIX, a więc okresie szczególnym w historii społeczeństw, z jego cechą charakterystyczną w postaci nowych idei, u których podstaw legła Rewolucja Francuska i wielka rewolucja przemysłowa, a które wywarły ogromny wpływ na życie ówczesnej Europy i odbiły się szerokim echem na pozostałych kontynentach. Zainicjowały epokę przemian, nie tylko w zakresie działalności politycznej i gospodarczej, ale także społecznej, której istotnym elementem była coraz większa świadomość praw i obowiązków, przemian, których punktem wyjścia była Europa, obdarzona pozycją dominującą na mapie świata, tak pod względem ekonomicznym, jak i ideologicznym.

Wówczas bowiem społeczeństwo muzułmańskie zostało zmuszone do przyjęcia europejskich osiągnięć z jednej strony i do wyrażenia własnej tożsamości wobec obcych wpływów z drugiej, w tym okresie pojawiły się takie ideologie jak panarabizm i panislamizm, dwa najważniejsze nurty w muzułmańskiej myśli XIX i XX wieku, których siłą przewodnią był najpierw zachwyt, potem rozczarowanie Zachodem, ale też doświadczenia europejskiego kolonializmu, którego ślady są nadal trwałe w świecie arabskim.

islamu. Patrz: J. Danecki, op. cit., s. 451-452; H. A. Jamsheer, Historia powstania islamu..., s. 121-133; H. A. Jamsheer, Reforma władzy..., s. 51-66.

12 'Abd ar-Raḥmān al-Kawākibī (1855-1902) - myśliciel syryjski, rozwijał koncepcje nacjonalizmu arabskiego i panarabizmu. Główne dzieła: Țabā' $i^{i}$ al-istibdād wa-mașāri ${ }^{\star}$ al-isti 'bād (Natura despotyzmu i cechy zniewolenia) i Umm al-Qurà (Matka Miast). Patrz: J. Danecki, op. cit., s. 452-453; H. A. Jamsheer, Historia powstania islamu..., s. 134-152; H. A. Jamsheer, Reforma władzy..., s. 67-88.

13 Muhammad Rašĩd Riḍà (1865-1935) - syryjski przedstawiciel nurtu modernistycznego XIX wieku opartego na salafiyyi, uczeń Muhammada 'Abduha, a w swoich koncepcjach bliski ideom Muhammada Ibn 'Abd al-Wahhāba. Postulował powrót do źródeł islamu - Koranu i sunny - tradycji Proroka oraz do oczyszczania go z wszelkich herezji i naleciałości - bid'a. Był zwolennikiem panislamizmu i reinterpretacji islamu celem przystosowania go do współczesności. Wiele jego idei legło u podstaw późniejszych ruchów fundamentalistycznych, a te, które powstały na gruncie jego koncepcji określa się mianem neosalafiyyi. Autor Al-Hiläfat aw al-imāmat al-uẓma (Kalifat czyli wielki imamat). Patrz: J. Danecki, op. cit., s. 485-486.

14 Hayr ad-Dīn at-at-Tūnusī (1822-1890) - tunezyjski polityk i reformator. Główne dzieło: Aqwam al-masālik fi márifat aḥwāl al-mamālik (Najprostsza droga do poznania sytuacji w królestwach). Patrz: J. Danecki, op. cit., s. 347-442. 
Na podłożu konfrontacji z ekspansją technologiczną, gospodarczą i ideologiczną Europy wyrastają reformy sułtanów Mahmūda $\mathrm{II}^{15} \mathrm{i}$ 'Abd alMağ̄ìda I ${ }^{16}$ W Imperium Osmańskim oraz „wicekróla” Egiptu, Muhammada "Alego ${ }^{17}$, pod którego panowaniem państwo to zaczęło odgrywać rolę głównej siły arabskiego odrodzenia cywilizacyjnego, określanego mianem An-Nahḍa (Odrodzenie). Pojawiają się koncepcje reformatorskie, szukające mechanizmów wyjścia z problemów, jakie niosła za sobą potęga i wielkość Zachodu, nowoczesne nauki i technologie, polityczne instytucje państwowe, socjalna moralność nowoczesnych społeczeństw. Starały się dać odpowiedź na fundamentalne pytanie o to, w jaki sposób cywilizacja arabsko-muzułmańska może się umocnić, by stawić czoło europejskiej i stać się częścią nowoczesnego świata.

Moderniści przekonywali, że islam jest zdolny do przetrwania w obliczu potęgi i postępu ówczesnej rzeczywistości, że nie tylko można go pogodzić z rozumem, postępem i solidarnością społeczną, a więc podstawami współczesnej cywilizacji, lecz nawet więcej - że w jego naukach można odnaleźć korzenie owych wartości. Takie poglądy reprezentował Ğamāl ad-Dīn Al-Afḡānī, twórca idei panmuzułmańskiej, postulujący syntezę zreformowanych i zmodernizowanych wartości kultury islamu z wartościami zapożyczonymi z Zachodu, w przekonaniu, że możliwe jest dostosowanie islamu do potrzeb nowoczesnego świata. Jego koncepcje rozwinął w praktyce jeden z jego uczniów i współpracowników, Egipcjanin Muhammad 'Abduh - prekursor panarabizmu, a kontynuowali je inni przedstawiciele świata arabsko-muzułmańskiego.

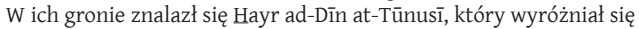
spośród innych reformatorów XIX wieku tym, że łączył w sobie dwie osobowości: reformatora i polityka, co sprawiło, że jego działalność nabrała

15 Mahmūd II (1785-1839) - sułtan turecki w latach 1808-1839, przeprowadził reformy w zakresie ustanowienia zasad sprawowania władzy, zreorganizował armię na wzór europejski, rozwiązał korpus janczarów w 1826 roku.

16 'Abd al-Mağìd (1823-1861) - sułtan turecki w latach 1839-1861. Zapoczątkował tan'ìmāt (,porządkowanie”) edyktem Hatt-i şerif z 1839 roku, w oparciu o który utworzono radę legislacyjną, ministerstwo spraw zagranicznych, wewnętrznych i handlu, a na podstawie kolejnego edyktu, Hatt-i Hümayun z 1856 roku, zreformował system administracji prowincji i system podatkowy. W 1850 wprowadził pierwszy kodeks handlowy, w 1869 zainicjował prace nad kodeksem postępowania cywilnego.

Muhammad “Alī (1805-1848) - „wicekról” Egiptu w latach 1805-1848 oraz 1848-1849, nazywany przez historyków twórcą potęgi tego kraju. Dzięki centralizacji władzy przeprowadził reformę rolną, administracyjną i edukacyjną, oparte na wzorcach europejskich. W literaturze polskiej działalność Muhammada 'Alego omawia praca B. Stępniewskiej-Holzer, Muhammad Ali, Ossolineum, Wrocław 1978. 
jedynego w swoim rodzaju charakteru poprzez realizację w praktyce idei wypracowanych w teorii. Całokształt myśli reformatorskiej zawarł w Najprostszej drodze do poznania sytuacji w królestwach (Aqwam al-masālikfïma'rifat aḥwāl al-mamālik) ${ }^{18}$, której najważniejszą częścią jest Prolegomena (Al-Muqaddima) zawierająca program reform. Rozważa w niej rozważa przyczyny zacofania i upadku świata arabsko-muzxułmańskiego oraz konieczność dokonania zmian z wykorzystaniem doświadczeń innych, w szczególności Zachodu, poprzez poznanie metod, które doprowadziły Europejczyków do obecnej potęgi i przejęcie tego, co jest przydatne w tymże świecie, bez odrzucania własnych wartości. Punktem wyjścia do unowocześnienia struktur i instytucji politycznych, społecznych i gospodarczych miało być spotkanie cywilizacyjne pomiędzy kulturą Zachodu a kulturą islamu. Według niego odzyskanie potęgi i bogactwa świata muzułmańskiego mogło nastąpić tylko i wyłącznie poprzez adaptację europejskich praktyk i instytucji politycznych, wszak te legły u podstaw obecnego stopnia rozwoju państw Zachodu.

Podstawą koncepcji reformatorskiej Hayr ad-Dīna jest rozważanie przyczyn supremacji europejskiej, których jego zdaniem nie należy upatrywać w warunkach naturalnych czy religii chrześcijańskiej, ale wyłącznie instytucjach politycznych (tanżimāt siyāsiyya): „Nie sądź, że jej mieszkańcy [Europy] zdobyli swoją pozycję dzięki większej żyzności czy też umiarkowanemu klimatowi, ponieważ mogą istnieć na kuli ziemskiej miejsca takie same bądź lepsze. I nie jest to wpływ ich religii, bo gdyby nawet religia chrześcijańska pobudziła rząd do realizacji sprawiedliwości i równości, to mimo wszystko, nie ingeruje ona w kwestie polityczne, ponieważ jej podstawy to pobożne życie oraz obojętność na sprawy

Hayr ad-Dīn at-Tūnusī, Aqwam al-masālik fì ma'rifat ahwāl al-mamālik, Al-Muğamma' atTūnusī li-al-'Ulūm wa-ăl-Adāb wa-ăl-Funūn "Bayt al-Ḥikma", Tunis 2004, s. 104. Rękopis znajduje się w Dār al-Kutub al-Wațaniyya w Tunisie pod numerem 110. Hayr ad-Dīn zakończył pisanie Najprostszej drogi. 9.09.1867 roku, a cztery miesiące później, dokładnie 14.01.1868 roku, uzyskał zgodę beja na oficjalną publikację i została wydana w postaci zeszytów, z których ostatni pojawił się w druku w sierpniu 1868 roku. Od tego czasu dzieło było trzykrotnie wydane w całości: w 1990, 2000 i 2004 roku, przez wydawnictwo Ministerstwa Kultury Al-Muğamma' at-Tūnusī li-l-'Ulūm wa-ăl-Adāb wa-ăl-Funūn "Bayt al-Hikma", z analizą tekstu i komentarzem Manșafa aš-Šanūfiego. Prolegomena do Najprostszej drogi.. doczekała się przekładu na język francuski Réformes nécessaires aux états musulmans (Paryż 1868) i angielski Necessary Reforms of the musulman states. Essay which forms the first part of the political and statistical work entitled „The surest way to know the state of the nations" (Ateny 1874). 
świata"19. Argumentem na poparcie owej tezy ma być fakt, że dobra koniunktura nie towarzyszyła Europejczykom nieprzerwanie na przestrzeni dziejów i nie zawsze znajdowali się na szczycie drabiny rozwoju cywilizacyjnego: „Obecna sytuacja w królestwach europejskich nie była stabilna od zawsze. Po ataku barbarzyńców z północy i upadku państwa rzymskiego w 476 roku znalazła się ona w stanie odrażającego zniszczenia, agresji i niesprawiedliwości, zaczęła zmierzać ku upadkowi, który jest znacznie szybszy niż dźwiganie się. Pozostawała w sidłach niewoli swoich królów oraz sąsiednich mocarstw aż do początków panowania Karola Wielkiego [...] Po jego śmierci Europa powróciła w mroki niewiedzy i niesprawiedliwości jej władców"20. obecnej siły i dobrej sytuacji politycznej, społecznej i gospodarczej Europy są jej rozwiązania polityczne, a więc odpowiedzialne ministerstwa i parlamenty, których funkcjonowanie scharakteryzował i przeanalizował w swoim dziele: „Przyczyną tego, o czym wspomnieliśmy jest postęp europejskiej wiedzy wynikającej z instytucji politycznych opartych na sprawiedliwości i wolności” ${ }^{21}$. Im przypisuje istotne znaczenie w rozwoju nauki, sztuki i gospodarki: „I osiągnęli te cele oraz postęp w nauce i produkcji dzięki instytucjom opartym na sprawiedliwości politycznej, a także dzięki działalności gospodarczej, eksploatacji skarbów ziemi oraz znajomości rolnictwa i handlu. Podstawą tego były bezpieczeństwo i sprawiedliwość, które stały się naturalne w tych krajach" "22. Elementem niezbędnym dla rozwoju jest więc bezpieczeństwo, będące bezpośrednią pochodną sprawiedliwych rządów: „Podstawą tego wszystkiego jest właściwe rządzenie oparte na bezpieczeństwie, a to przynosi nadzieję, doskonałość w pracy, co widać w państwach europejskich tak jasno, że nie potrzebne są wyjaśnienia" ${ }^{23}$. Wolność jest więc pierwszym i ostatnim warunkiem rozkwitu gospodarczego: „Do obowiązków państw, które posiadają przywilej wolności, choćby osobistej, należy odpłacanie tego błogosławieństwa poprzez ukazanie jej efektów, zbieranie jej owoców oraz wykorzystanie wiedzy" ${ }^{24}$. Jej brak prowadzi do upadku i zacofania gospodarczego: „Gdy królestwo

19 Hayr ad-Dīn at-Tūnisī, Aqwam al-masālik fì márifat ahı̄ōl al-mamālik, Al-Muğamma‘ atTūnusī li-al-'Ulūm wa-ăl-Adāb wa-ăl-Funūn "Bayt al-Hikma”, Tunis 2004, s. 103-104.

Ibidem.

Ibidem, s. 105.

Ibidem.

Ibidem, s. 106.

Ibidem, s. 193. 
nie posiada wolności, brak w nim również wygody i bogactwa, jego mieszkańców gnębi bieda i drożyzna, słabnie przenikliwość i ambicja" ${ }^{25}$.

W ten sposób Hayr ad-Dīn wyraźnie określa podstawowy warunek umożliwiający wyjście z zacofania i regresu, które dotknęły społeczeństwo arabsko-muzułmańskie, a mianowicie - oparcie gospodarki na metodach i wzorcach europejskiego modelu społeczeństwa kapitalistycznego: ułatwienia komunikacyjne poprzez budowę linii kolejowych, różnorodność organizacji handlowych, zgoda na przejęcie wiedzy dotyczącej rzemiosła i przemysłu, tworzenie spółek kapitalistycznych, unowocześnienie banków, organizowanie regionalnych i międzynarodowych targów handlowych, itd. ${ }^{26}$ Omawiając etapy rozwoju cywilizacji europejskiej na przestrzeni wieków, jej odkrycia, wynalazki, system szkolnictwa, autor miał na celu wyrażanie swojej pochwały dla produktów wolności w społeczeństwie europejskim ${ }^{27}$.

Przedstawienie przyczyn supremacji europejskiej, a następnie wizerunku zachodniej cywilizacji jest celowym posunięciem Hayr ad-Dīna i jednym z elementów jego koncepcji reformatorskiej prowadzącym do kolejnego punktu - adaptowania obcych wzorów do świata arabsko-muzułmańskiego bez naruszenia tradycyjnego systemu wartości i norm, co ma stanowić podstawę do unowocześnienia tego świata, przystosowania go do nowych okoliczności i wyjścia z upadku w kierunku rozwoju i postępu we wszystkich dziedzinach życia.

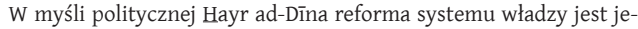
dynym środkiem prowadzącym do ustanowienia sprawiedliwości ('adl) i wolności (hurriya), a wolność jest podstawą cywilizacji (asās al-umrān). Analizując historię cywilizacji arabsko-muzułmańskiej w okresie jej rozkwitu oraz rozwiniętą cywilizację europejską w epoce mu współczesnej, dochodzi do wniosku, że ich podstawą jest wolność: „Wolność jest źródłem wiedzy i cywilizacji w państwach europejskich" ${ }^{28}$. Podkreśla, że: „Państwa, które osiągnęły najwyższy stopień cywilizacji to takie, w których wolność zapuściła korzenie ${ }^{29 "}$.

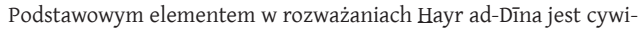
lizacja (at-tamaddun), uznana przez niego za „mądrość, która jest bronią wiernego, winien ją zabierać wszędzie tam, gdzie ją znajdzie”, ${ }^{\text {, a szcze- }}$

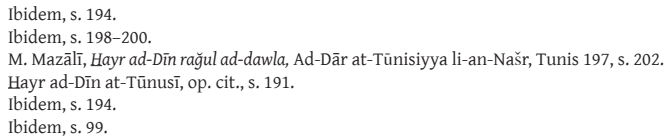


gólnie zobowiązani są do tego „ludzie polityki” i „ludzie religii”, dlatego uzasadnienie owej konieczności winno opierać się na argumentach racjonalnych (ḥuğăg 'aqliyya) i historycznych (huğağ naqliyya). Jak mówi: „Celem przypomnienia metod, które doprowadziły królestwa europejskie do ich potęgi i władzy jest wybranie z nich takich, które odpowiadałyby naszej sytuacji oraz byłyby pomocne i zgodne z tekstem šarĩa. Być może uda nam się odzyskać to, co zostało wzięte z naszych rąk i wyeliminować marnotrawstwo. Nie będziemy w stanie dokładnie określić co jest dla nas odpowiednie, jeżeli nie poznamy tego, kto nie jest jednym z nas, zwłaszcza gdy nas osaczył i ulokował się tuż obok" ${ }^{31}$. Przytacza tu argument racjonalny (huğğa 'aqliyya) na poparcie tego stwierdzenia i sposobu myślenia, który uznaje za błędny: „A skoro pokolenie naszych prawowitych przodków czerpało wiedzę, w tym logikę, od innych i dokonało przekładów z greki, gdy tylko dostrzegło w tym korzyść, co sprawiło, że rzekł AlGazālīi ${ }^{32}$ : „Nie można ufać wiedzy tego, kto nie zna logiki”, to jakie mamy dziś przeciwwskazania, aby nie czerpać z części ich wiedzy, której - jak sami zauważamy - ogromnie potrzebujemy, by odrzucić to, co nam szkodzi i przejąć to, co przynosi korzyść" ${ }^{33}$. Następnie przytacza argument historyczny (huğğa naqliyya): „Kiedy Salmān al-Fārisi ${ }^{-34}$ - oby Bóg był z niego zadowolony - dał radę Prorokowi - pokój z Nim - mówiąc, iż zwyczajem Persów jest okopywanie miasta rowem, gdy zostaną otoczeni przez wroga i obawiają się ataku z jego strony, ten postąpił zgodnie z ową radą i wykopał rów wokół Medyny podczas bitwy Al-Ạ̣zāb ${ }^{35}$. Nasz Pan 'Alī - niech będzie pochwalony - rzekł: „Nie rozpatruj tego, kto powiedział, ale to, co powiedział" $"$.

W opinii Hayr ad-Dīna nierozważni muzułmanie unikali europejskich praktyk i instytucji politycznych mimo braku ich sprzeczności z šarīa tylko dlatego, że byli w pełni przekonani, iż należy odrzucać wszystko to, co pochodzi od nie-muzułmanów. Tymczasem taka postawa

Ibidem, s. 97.

Abū Hamīd Muhammad Ibn Muhammad al-Ḡazālī (1055-1111), znany w Europie pod zlatynizowanym imieniem Algazel - muzułmański teolog i filozof, krytyk racjonalistycznych i naturalistycznych tendencji w filozofii arabskiego średniowiecza. Uważał, że filozofia powinna być podporządkowana ortodoksyjnemu islamowi.

Ibidem, s. 100.

34 Salmān al-Fārisī (zm. 656) - niewolnik, chrześcijanin, potem muzułmanin, po uzyskaniu wolności został członkiem „domu Proroka”. Przeszedł do historii dzięki sugestii charakterystycznej dla Persów fortyfikacji Medyny poprzez wykopanie rowu, co sprawiło, że miasto odparło atak Mekkańczyków.

35 Wydarzenie to miało miejsce w 627 roku i przeszło do historii pod nazwą Bitwy Rowu.

36. Ibidem, s. 99. 
nie ma uzasadnienia, zwłaszcza, że owe praktyki i instytucje nie tylko nie są niezgodne z tekstem prawa muzułmańskiego, ale wręcz znajdują w nim swoje korzenie, były bowiem praktykowane przez samych muzułmanów: "Jeżeli rzecz pochodziła od obcych, ale zgodnie z dowodami była słuszna, a zwłaszcza gdy należała do nas i została nam odebrana, to nie istnieje powód, aby ją odrzucać i lekceważyć. Wręcz przeciwnie - należy dążyć do jej odzyskania i zastosowania"37. Hayr ad-Dīn wzywa więc muzułmanów do pokonania przeszkód religijnych i do tego co nazywamy dzisiaj „otwartością" (at-tafattuh): „Zadaniem przenikliwego obserwatora jest odróżnienie prawdy przez wnikliwą analizę przedmiotu badania, niezależnie od tego czy są nim słowa czy czyny, a jeśli stwierdzi, że są słuszne, akceptuje je i idzie ich śladem, bez względu na to skąd pochodzą "38. Podsumowuje stwierdzeniem, że to, co jest słuszne, zasługuje na naśladowanie, ponieważ: „Dobrych uczynków nie poznaje się po tych, którzy je czynią, ale ludzi poznaje się po ich dobrych uczynkach” (Fa-laysa bi-ăr-riğāl yu'araf al-haqq bal bi-ăl-haqq tu'araf ar-riğăl $)^{39}$, do którego dodaje sentencję znaną w tradycji muzułmańskiej: „Mądrość jest bronią wiernego, winien ją zabierać wszędzie tam, gdzie ją znajdzie" (Al-hikma ḍalat al-mu'min, ya'huduhā haytu wağadahō $)^{40}$.

Jeśli chodzi o zakres naśladowania Zachodu i jego ukierunkowanie to Najprostsza droga... szczegółowo określa jego kształt i wymiar - ograniczając owo naśladowanie do Rewolucji Francuskiej, która wybuchła w 1789 roku i rewolucji przemysłowej, której rozkwit nastąpił w połowie XIX wieku oraz do skutków tych wydarzeń w zakresie ideowym i cywilizacyjnym, a co za tym idzie - ich rezultatu w zakresie rozwoju i postępu. Wszystko to są przykłady, do których odwołuje się Hayr ad-Dīn wzywając do pójścia śladami Zachodu i wyjaśniając zasady, którymi należy się w tym naśladownictwie kierować.

W słowach $\underline{H}$ ayr ad-Dīna wyraźnie zauważamy krytykę postawy części społeczności muzułmańskiej wobec materialnych i niematerialnych aspektów kultury europejskiej, zwłaszcza sprzeczności, którą dostrzega w tejże postawie, a mianowicie - akceptacji jednych, a odrzucaniu innych zapożyczeń Zachodnich: „Jeżeli przyjrzymy się sytuacji tych, którzy zaprzeczają temu, co dobre w dokonaniach Europejczyków stwierdzimy, że odrzucają naśladowanie tego, co jest korzystne w insty-

\footnotetext{
Ibidem.

Ibidem.

Ibidem, s. 105.

Ibidem.
} 
tucjach politycznych i efektach ich działania, a nie odrzucają tego, co im szkodzi. Widzimy jak prześcigają się w zakupie strojów, wyposażenia wnętrz i innych niezbędnych rzeczy, jak broń i akcesoria wojenne" $e^{\text {"41 }}$. Zauważa w tym mechanizm, który prowadzi do zubożenia i osłabienia pozycji świata muzułmańskiego na skutek braku samowystarczalności i oparcia się na innych w zdobywaniu podstawowych produktów: „Pasterze, producenci jedwabiu i bawełny ciężko pracują przez cały rok i to, co wyprodukowali, sprzedają za niską cenę Europejczykom. Wkrótce potem odkupują to od nich w formie przetworzonych dóbr płacąc ponad dwukrotnie więcej niż sami otrzymali" ${ }^{42}$. Szczególnego zagrożenia upatruje Hayr ad-Dīn w uzależnieniu świata arabsko-muzułmańskiego od innych w kwestii uzbrojenia i wojskowości, co implikuje polityczną słabość i utrudnienie w dążeniu do suwerenności. Tu po raz kolejny odwołuje się do słów Proroka Muḥammada, który twierdził: „Kto walczy, niech walczy tak jak przeciwnik" (Man qātil falyuqātil kamā yuqātal) ${ }^{43}$, sugerując, że muzułmanie winni naśladować osiągnięcia militarne swoich wrogów, korzystać z ich osiągnięć i taktyk stosowanych w tej dziedzinie. Autor dążył do rozszerzenia tego stwierdzenia poza treści militarne, obejmując nim zagadnienia naśladownictwa instytucji politycznych, gospodarczych i edukacyjnych. Przekonywał, że u podstaw siły i potęgi militarnej, niezbędnej dla uzyskania niezależności i mocy państwa, leżą odpowiednia wiedza i postęp, te zaś są uwarunkowane istnieniem stosownych organizacji politycznych.

Hayr ad-Dīn odrzuca całkowicie stanowisko fundamentalistów, a zwłaszcza 'ulamā', którzy sprzeciwiają się jakiemukolwiek otwarciu na Zachód i dialogowi z nim, wzywając do powrotu do korzeni: „Część 'ulamā', którym z uwagi na ich rzetelność i uczciwość powierza się dbanie o zgodność prawa z wymogami czasu, więc ich udziałem winno być rozpatrywanie wydarzeń wewnętrznych i otwieranie umysłów na wiedzę pochodzącą zzewnątrz, wyraźniesięprzed tymuchyla.Niejesttajemnicą, żejesttojedna z najpoważniejszych przeszkód na drodze ku pozyskaniu wiedzy, którą należy uwzględnić w odpowiedni sposób" ${ }^{\text {"4 }}$.

Jeśli chodzi o rozwiązanie, które proponuje Hayr ad-Dīn, ma nim być naśladowanie w granicach prawa muzułmańskiego: „Celem przypo-

\footnotetext{
Ibidem, s. 101.

Ibidem, s. 102.

Ibidem.

Ibidem, s. 95.
} 
mnienia metod, które doprowadziły królestwa europejskie do ich potęgi i władzy jest wybranie z nich takich, które odpowiadałyby naszej sytuacji oraz byłyby pomocne i zgodne z tekstem šarĩ 'a" $a^{\text {"45 }}$. Zakres naśladowania obejmuje wiedzę Europejczyków (al-ma‘ārif) i instytucje polityczne (tanżimāt) oparte na sprawiedliwości ('adl) i wolności (hurriya), które są z natury przynależne prawu muzułmańskiemu, a to prowadzi Hayr adDīna do rozwiązania tej kwestii poprzez ożywienie wartości muzułmańskich, które zostały zapomniane na skutek pojawienia się herezji i nowinek, w tym głównej z nich - władzy absolutnej (hukm muṭlaq).

Hayr ad-Dīn wyraźnie odróżnia prawo religijne (šarĩa islāmiyya) i prawo świeckie ( qānūn 'aqlī), poświęcając wiele uwagi temu pierwszemu, które „obowiązuje muzułmanów tak w życiu religijnym, jak i świeckim, przy czym uznaje je za całkowicie słuszne" ${ }^{\text {"46 }}$. Argumentuje to dowodami historycznymi wskazując, że kiedy stanowiło ono podstawę rządów, świat arabsko-muzułmański stał na szczycie drabiny cywilizacyjnej, kiedy zaś zostało zaniedbane, zaczął chylić się ku upadkowi. Doskonałe i wieczne prawo muzułmańskie wraz z jego systemem wartości sprawiło, że islam zaledwie w 80 lat dokonał tego, na co Rzymianie potrzebowali ośmiu wieków: „W dziele zatytułowanym Przyjemność dla oczu ${ }^{47}$ przetłumaczonym z języka francuskiego przez Egipcjanina, szajcha Aḥmada az-Zarābīego, uważanym za jedną z najlepszych egipskich publikacji, wspomniano, że islam podbił w ciągu osiemdziesięciu lat więcej ziem niż Rzymianie na przestrzeni lat ośmiuset" ${ }^{\text {"48 }}$. Na potwierdzenie wysokiego stopnia rozwoju cywilizacji muzułmańskiej w owym czasie przytacza relacje europejskich uczonych, historyków francuskich: Victora Duruya, ministra oświaty oraz Sedillota, wykładowcy historii w Collège de France, z których pierwszy pisał: „Gdy Europejczycy błąkali się w mroku niewiedzy od strony ummy muzułmańskiej jaśniało silne światło literatury, filozofii, produkcji, rzemiosła i nie tylko"49 , a drugi przypisywał szczególną rolę Arabom twierdząc, że „bez wątpienia Arabowie są naszymi nauczycielami i mistrzami" ${ }^{50}$.

Hayr ad-Dīn zauważa, że w świecie arabsko-muzułmańskim nastąpił regres, kiedy „podzielił się na trzy państwa: Abbasydzkie w Bagdadzie

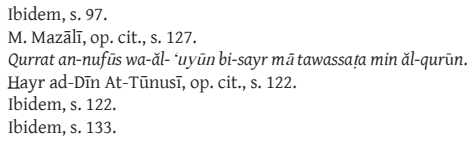


i na Wschodzie, fatymidzkie w Egipcie i Afryce Północnej oraz Umajjadów w Andaluzji. [...] Przyczyną tych podziałów była sprzeczność interesów i egoistycznych namiętności emirów i rebeliantów, którzy nie brali pod uwagę szkód dla ogółu" ${ }^{51}$. Konsekwencją upadku cywilizacji arabsko-muzułmańskiej, spowodowanego odejściem od prawa muzułmańskiego (šarỉa islāmiyya), była władza absolutna i tyrania. Jak mówi: „W związku ze skłonnościami natury ludzkiej, pozostawienie pełnej niezależności królom było przyczyną niesprawiedliwości w całej jej różnorodności. Ma to miejsce dziś w niektórych krajach muzułmańskich i zdarzało się w królestwach Europy w wiekach despotyzmu ich królów" ${ }^{\text {"52. }}$.

Omawiając zagadnienie likwidacji władzy absolutnej autor wyróżnia i charakteryzuje trzy typy władców, które charakteryzuje w następujący sposób: „Albo posiada pełnię wiedzy i umiłowanie dobra ojczyzny, jest zdolny do realizacji tego, co korzystne, dbając o to, co najbardziej właściwe, albo posiada pełnię wiedzy, lecz jego osobiste cele i namiętności nie pozwalają mu na dbanie o interes ogółu, albo nie posiada żadnej wiedzy" 53 . Jak stwierdza, od władcy zależy system władzy, który przenosi się na całą administrację państwową. Podkreśla także, że działanie w oparciu o jedną opinię jest błędne, nawet wtedy, kiedy opiniodawca osiągnął pełnię doskonałości i wiedzy, jest bowiem przekonany, że ludzka natura sprawia, iż pozostawienie władcy całkowitej swobody działania implikuje skłonność do różnego rodzaju złych praktyk, niesprawiedliwości i nadużyć. Autor posługuje się tu przykładem Napoleona I, który jak tylko wzrósł w siłę, zmienił się w szalonego dyktatora. Ostro krytykuje go, wspominając przypisywane chrześcijanom umiłowanie sprawiedliwości, mówi: „Z myśli Arystotelesa pochodzi mądrość, iż poważnym błędem jest zastąpienie prawa jedną osobą postępującą zgodnie z własną wolą. [...] Człowiek stworzony jest do umiłowania wolności i nienawiści wobec tyranii władców" ${ }^{54}$. Przyznaje, że dyktatura pojawiła się już u Rzymian, wskazuje jednak na fakt, iż była ona uzasadniona okolicznościami, które wymagały wprowadzenia takiej, a nie innej formy rządów: „Potrzeba wzywa do przekazania zarządzania państwem jednej despotycznej osobie, ale na ograniczony okres i w oparciu o określone warunki" ${ }^{55}$.

\footnotetext{
Ibidem.

Ibidem, s. 106 ,

Ibidem, s. 109.

Ibidem, s. 119.

Ibidem, s. 205.
} 
Budując koncepcję likwidacji władzy absolutnej (hukm muṭlaq) i konieczności istnienia siły rozdzielającej (wāzi $\left.{ }^{2}\right)$ Hayr ad-Dīn odwołuje się do teorii politycznej Ibn $\underline{\text { Haldūna }}{ }^{56}$ przedstawionej we Wstępie (Al-Muqad$\operatorname{dima}^{57}$ ) do wielkiej historii uniwersalnej Kitāb al-'ibar wa dīwān al-mubtada' wa-ăl-habar fì 'ayyām al-'arab wa-ăl-'ağam wa-ăl-barbar wa man 'āsarahum

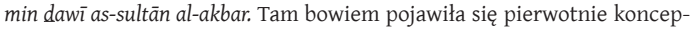
cja siły hamującej, niezbędnej w każdym społeczeństwie celem unikania krzywd, zniszczenia i agresji, leżących u podstaw zwierzęcej natury człowieka, siły nazywanej przez niego wāzi lub ḥukm al-wāzi'. Jej ucieleśnieniem ma być osoba dominująca nad innymi, charakteryzująca się siłą i władzą, która umożliwia mu zapanowanie nad nimi i ich instynktami, a osobą tą winien być ten, kto sprawuje władzę królewską (mulk). Hayr

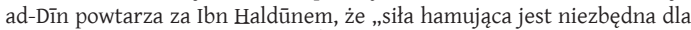
przetrwania gatunku ludzkiego" ${ }^{, 58}$, ale dodaje, że może ona ulec wypaczeniom jeśli „pozwolono by jej czynić to, na co ma ochotę i rządzić zgodnie z własną wolą" ${ }^{59}$. Jedyne możliwe rozwiązanie dostrzega w kontrolowaniu owej siły wāzit przez kolejną siłę wāzi‘ w postaci prawa religijnego (šarĩa) lub świeckiego (qānūn 'aqlī). Mówi: „Moim zdaniem, gdyby nie siła hamująca, o której była mowa wcześniej, żadna ludzka władza nie byłaby właściwa, bowiem jest ona niezbędna dla przetrwania gatunku ludzkiego. Gdyby pozwolono owej sile czynić to, na co ma ochotę i rządzić zgodnie z własną wolą, wówczas nie wydałaby owocu, dla którego została ustanowiona ponad wspólnotą, zatem konieczne jest poddanie jej kontroli kolejnej siły rozdzielającej w postaci prawa religijnego bądź świeckiego. Żadne z nich nie ochroni swych praw, jeśli zostaną naruszone, dlatego obowiązkiem uczonych tejże wspólnoty i wybitnych jej przedstawicieli jest zmiana tego, co naganne"

Hayr ad-Dīn wychodzi od następującego stwierdzenia: „Prawo muzułmańskie przyniosło najlepsze rezultaty w przeszłości, nie ma absolutnie żadnego powodu, by nie dało podobnych rezultatów w teraźniejszości

56 Ibn Haldūn (1332-1406) - arabski filozof, historyk, prekursor socjologii, politologii i ekonomii, któremu przypisuje się stworzenie arabskiej filozofii historii i socjologii. Jego dzieła wywarły duży wpływ na średniowieczną kulturę.

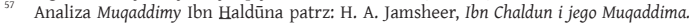
Antologia myśli społeczno-politycznej, Łódź 2002; H. A. Jamsheer, Ibn Chaldun.MuqaddimaHistoria - Historiozofia, Łódź 1998, J. Bielawski, Ibn Chaldum, Warszawa 2000.

Hayr ad-Dīn At-Tūnusī, op. cit., s. 107.

Ibidem.

Ibidem, s. 107. 


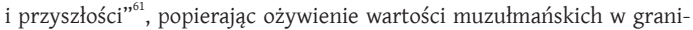
cach adekwatnych do panującej sytuacji, bowiem kiedy zmienia się świat, zmieniają się potrzeby społeczeństwa, a prawo i polityka winny przystosować się do tych zmian. Uważał, że utrzymywanie kontaktów pomiędzy teologami ('ulamā') a politykami (riğāl as-siyāsa) w celu współpracy we wspomnianym wyżej celu jest jednym z najważniejszych ich obowiązków: „Utrzymywanie relacji pomiędzy 'ulamā' i politykami celem współpracy we wspomnianych dążeniach jest jednym z najważniejszych obowiązków wynikających z prawa muzułmańskiego celem realizacji interesów ummy, podobnie jak konieczność obeznania ulamā' z wydarzeniami bieżącymi, na których znajomości opiera się sprawowanie władzy"62. Rolą polityków jest przedstawianie nowych założeń i planów politycznych, które mają służyć dobru społeczeństwa, zaś zadaniem 'ulamā' jest określenie czy pozostają one w zgodności z wartościami i zasadami šarīa. Warunkiem prawidłowego funkcjonowania tejże współpracy jest ich wzajemne porozumienie i poszanowanie, ale przede wszystkim podążanie "ludzi religii” za duchem czasu i ich zbliżenie do „ludzi polityki” i spraw państwa.

Polityka idąca w parze z prawem muzułmańskim, do której wzywa Hayr ad-Dīn nie jest jednak wiernym naśladownictwem pokolenia przodków (salaf șālih), lecz opiera się na podstawach adekwatnych do wymogów epoki. Autor przywołuje tu fragmenty z pism Muhammada Bayrama I ${ }^{63}$, w których scharakteryzował on politykę podlegającą prawu muzułmańskiemu: „Władza oparta na prawie muzułmańskim najbardziej przybliża ludzi do korzyści i najbardziej oddala ich od zepsucia" ${ }^{64}$. Jest przekonany, że „nie ma innej władzy niż ta, która jest zgodna z prawem muzułmańskim", dlatego podkreśla, że polityka winna być oparta na prawie muzułmańskim i wspierana działaniem teologów, bowiem šarīa, u której podstaw leżą sprawiedliwość, równość i wolność, daje konkretne i bardzo precyzyjne zasady funkcjonowania państwa, a ich przestrzeganie

61

63 Muhammad Bayram I (1840-1889) - studiował na Uniwersytecie Az-Zaytūna, brał czynny udział w działalności politycznej i reformatorskiej we współpracy z Hayr ad-Dīnem at-Tūnusīm, kierował pismem „Ar-Rā'id at-Tūnusī”, dużo podróżował, zwłaszcza od roku 1878, autor dzieła Șafwat al-itibār (Jednym słowem), pod koniec życia osiedlił się w Egipcie, gdzie od 1884 roku wydawał czasopismo "Al-I‘lām” (,Wiadomości”).

${ }^{64}$ Hayr ad-Dīn At-Tūnusī, op. cit., s. 148.

65 Ibidem. 
stanowi gwarancję właściwej administracji, dobra powszechnego i postępu cywilizacyjnego.

Hayr ad-Dīn nie wzywa do zmiany systemu władzy, lecz w jego myśli, podobnie jak w koncepcjach większości współczesnych mu reformatorów, jak choćby Ibn Abī aḍ-Dayyāf ${ }^{66}$ - przeważają rozważania mające na celu zagwarantowanie sprawiedliwości ('adl) i wolności (ḥurriya), jako wartości, które są ,podstawą prawa muzułmańskiego” i wyznacznikiem na drodze postępu i rozwoju. Wartości te winny być ukonstytuowane i chronione suwerennym prawem, a poszanowanie owego prawa prowadzi z jednej strony do rozwoju państwa: „Narody, które osiągnęły najwyższy stopień prawości to te, które szanują swoje prawo oparte na sprawiedliwości politycznej, podczas gdy nieposzanowanie prawa stanowiło przyczynę ich regresu", a z drugiej strony do ochrony jego obywateli: „W europejskich królestwach szacunek i nieprzerwane oddziaływanie prawa pod nadzorem ahl al-hall wa-ăl-aqd ${ }^{67}$ zabezpiecza prawa poddanych i ich wolność oraz chroni słabych przed tyranią silnych, a także broni pokrzywdzonych przez despotyczną władzę"68.

Relacje władca - prawo określają przytoczone przez Hayr ad-Dīna słowa: „W społeczeństwie greckim, gdzie - kiedy wróg opanował część ich kraju i zmusił mieszkańców do opuszczenia go - zapytano pochodzącego spośród nich mędrca: „Gdzie najlepiej zamieszkać?”, a on odpowiedział im: „W kraju, w którym prawo jest silniejsze od władcy” ". Ważne jest podkreślenie autora, że „prawo jest wiążące zarówno dla władców, jak i dla poddanych" ${ }^{, 70}$, co implikuje jego kolejny wniosek, a mianowicie, że stan państw zarządzanych bez zastosowania prawa uwarunkowany jest kompetencjami sprawujących rządy: „W królestwach, w których administracja nie ma swoich sprecyzowanych praw strzeżonych przez ahl al-hall wa-ăl-'aqd, bogactwo i niepowodzenie sprowadza się do osoby króla, a rozmiar ich sukcesu uwarunkowany jest jego potęgą i praworządnością," ${ }^{\text {,1 }}$. Konieczne jest zatem ustanowienie praw, które - jak mówi Hayr

66 Ibn Abī aḍ-Ḍayyāf,, op. cit., rozdział 1, Wstęp (Al-Muqaddima), Władza absolutna (AlHukm al-muțlaq), Władza ograniczona prawem (Al-Hukm al-muqayyad bi-qanūn), Władza demokratyczna (Al-Hukm al-ğumhūrī).

67 Ahl al-hall wa-ăl-aqd - "ci, co rozwiązują i zawiązują", decydenci, w klasycznej myśli muzułmańskiej grupa osób uprawnionych do dokonywania w imieniu społeczności muzułmańskiej wyboru kalifa.

Hayr ad-Dīn At-Tūnusī, op. cit., s. 112.

Ibidem, s. 205.

Ibidem, s. 191.

Ibidem, s. 112. 
ad-Dīn - dzielą się w państwach europejskich na dwie kategorie, a mianowicie - przepisy regulujące stosunki pomiędzy państwem i poddanymi oraz normy dotyczące wzajemnych relacji obywateli. Pierwsza kategoria dotyczy praw i obowiązków państwa, a w jej zakres wchodzą następujące kwestie: wolność obywatelska, którą gwarantuje ochrona praw obywateli, określenie podstaw prerogatyw państwa republikańskiego lub monarchii, takich jak zastosowanie przepisów prawnych, kierowanie polityką wewnętrzną i zagraniczną, działania wojenne oraz zawieranie traktatów pokojowych i handlowych, nadawanie urzędów, mianowanie ministrów i innych urzędników państwowych, a także pobieranie podatków. Dodaje, iż: „Ustanowienie tej kategorii praw ma miejsce we Francji za zgodą większości ludzi prawych spośród mieszkańców państwa, korzystających z praw osobistych i politycznych, podczas gdy w innych wymagane są poza wspomnianymi warunkami bądź to odpowiednia wiedza, bądź posiadanie określonej kwoty podlegającej opłacie, bądź też rodzaj prestiżu nazywany przez nich „szlachectwem”. Wyrażenie zgody następuje osobiście bądź za pośrednictwem wybieranego do tej czynności pełnomocnika" ${ }^{\text {72 }}$. Druga kategoria obejmuje prawa ustanowione dla rozstrzygania spraw mieszkańców, a ,ich ustanowienie tej kategorii praw i ich modyfikacja w sposób właściwy dla sytuacji następuje poprzez zgodę dwóch rad, Najwyższej Rady ${ }^{73}$ - złożonej z członków rodziny królewskiej i osób wybranych dożywotnio przez króla spośród wybitnych osobistości państwa oraz Rady Reprezentantów ${ }^{74}$ - złożonej z osób wybieranych przez naród celem ochrony jego praw i dbania o praworządność państwa"75.

Władza ma być więc ograniczona prawem, a ograniczenie to zobowiązuje władcę nie tylko do zmiany i eliminacji tego, co niesłuszne (taḡyir al-munkar), ale także do słuchania rad teologów ('ulamā') i decydentów (ahl al-ḥall wa-ăl-'aqd). W koncepcji konsultowania (mašwara) opiera się na teorii prawnika Ibn al-'Arabīego ${ }^{76}$, zgodnie z którą: „Nie ma sprawiedliwości, jeśli się odrzuca doradztwo" (lā sawāba ma'a tark al-mušāwara).

Ibidem, s. 201.

73 Najwyższa Rada - autor ma na myśli izbę wyższą. Występuje pod nazwami: Izby Lordów (Wielka Brytania), Izby Parów (Francja 1814), Izby Panów (Prusy, Austria), Senatu (Stany Zjednoczone, Francja 1875, Polska), Rady Starszych (Francja 1795), Rady Państwa (Rosja 1906, Polska 1952), Rady Związkowej (Niemcy 1871).

Rada Reprezentantów - autor ma na myśli izbę niższą. Występuje pod nazwami: Izby Gmin (Wielka Brytania), Izby Deputowanych (Francja), Izby Reprezentantów (Stany Zjednoczone), Reichstagu (Niemcy), Dumy Państwowej (Rosja).

75 Hayr ad-Dīn At-Tūnusī, op. cit., s. 201.

76 Abū Bakr Muhammad Ibn 'Abd Allāh znany jako Ibn al-'Arabī (1076-1148) - nie chodzi tu o słynnego przedstawiciela sufizmu (Muhȳ̄ ad-Dīn Abū Bakr Ibn Muhammad), 
Ograniczenie autorytetu władcy jest w myśli politycznej Hayr adDīna usprawiedliwione koncepcją konsultacji (mušāwara), wywodzącą się z muzułmańskiej idei šūrá, która oznaczała koraniczny nakaz naradzania się Proroka Muhammada z przedstawicielami ummy ${ }^{77}$. Autor podkreśla, że Bóg zesłał Rasūlowi ów nakaz, choć był on powszechnie uznany za doskonałego i nieomylnego, a zważywszy na jego boskie natchnienie nie miał potrzeby konsultowania się ani słuchania rad jakichkolwiek ludzi czy złożonych z nich organów, mimo to mušāwara miała stać się częścią sunny - tradycji obowiązującej pierwszego i kolejnych władców społeczności muzułmańskiej. Poparciu tej tezy, a więc słuszności i konieczności konsultacji mają służyć przytoczone opinie: prawnika Ibn al-'Arabiego, kalifów 'Alego Ibn Abī Ṭāliba ${ }^{78}$, 'Umara Ibn al-Ȟațāaba ${ }^{79}$ i Mu'āwiyi ${ }^{80}$ oraz teologa Al-Ğazālego: „Ibn al-'Arabī powiedział: „Konsultacja jest podstawą religii i sunny boskiej w obu światach (al-mušāwarat aṣl ad-dīn wa sunnat Allāh fi ăl'ālamayn). Prawo to obowiązuje ogół stworzeń od proroka aż po najmniejszą istotę”. A oto słowa “Alego - oby Bóg był z niego zadowolony: „Nie jest słuszną rezygnacja z konsultowania" (lā sawāb fì tark al-mušāwara) [...] Muzułmański autorytet, Al-Ḡazālī, twierdził: „Kalifowie i królowie muzułmańscy domagają się reakcji nawet przemawiając z kazalnicy”. “Umar Ibn al-H_ațtāb - oby Bóg był z niego zadowolony - powiedział podczas kazania: „Jeżeli zbłądzę, o wierni, przywróćcie mi równowagę”. Odpowiedział mu jeden z muzułmanów: „Na Boga, “Umarze, przywrócimy ci ją przy pomocy ostrzy naszych mieczy"

W oparciu o argument, że działanie na podstawie jednej opinii (bi-ăr-ra'y al-wāhid) jest błędne, Hayr ad-Dīn postuluje konsultację władcy z decydentami (ahl al-hall wa-ăl-'aqd), a więc ich udział w sprawowaniu rządów i sprawach politycznych państwa. Przyznaje, że istnieją monarchowie obdarzeni cechami, które pozwoliłyby im rządzić bez odwoły-

zwanego również Ibn al-‘Arabī - muzułmański uczony z Hiszpanii, uczeń Al-Ḡazālego, autor komentarzy do Koranu i hadisów.

77 Tytuł Šūrà (Narada) nosi XLII sura Koranu, której wers 38 wspomina, że „sprawy są przedmiotem wzajemnej narady", Koran, przekład J. Bielawski., Warszawa 1986, s. 583.

78 'Alī Ibn Abī Ṭālib (ok. 600-661) - brat stryjeczny, przybrany syn, a następnie zięć Muhammada, pierwszy imam szyitów, ostatni z czterech tzw. kalifów prawowiernych (656-661).

79 'Umar Ibn al-Hattāā (591-644) - drugi z czterech tzw. kalifów prawowiernych (634-644), jeden z twórców potęgi imperium arabsko-muzułmańskiego.

80 Mu'āwiya Ibn Abū Sufyān (602-680) - założyciel dynastii Umajjadów, kalif w latach 661-680.

${ }^{81}$ Hayr ad-Dīn At-Tūnusī , op. cit., s. 106-107. 
wania się do konieczności mušāwara, pod warunkiem, że mieliby oparcie w mądrych i wyrozumiałych ministrach, jednak dodaje, że takie sytuacje należą do rzadkości.

Hayr ad-Dīn podkreśla, że współuczestniczenie w rządach decydentów na zasadzie konsultacji w żaden sposób nie narusza autorytetu władcy: „Nie można stwierdzić, że „współpraca ahl al-hall wa-ăl-aqd $\mathrm{z}$ władcami $\mathrm{w}$ sprawowaniu władzy ogranicza autorytet władcy i jego kompetencje" ${ }^{\prime \prime 2}$, jest natomiast czynnikiem, który zapewnia państwu zapewnia „trwałość i znaczne korzyści”, ${ }^{\text {,3 }}$. Jest przekonany o konieczności konsultacji (mušāwara) i zmiany tego, co naganne (taḡyīr al-munkar) przez ahl al-ḥall wa-ăl-'aqd: ,Jest więc jasne, że legitymizacja udziału šūry w ogólnej polityce [...] jest jak najbardziej właściwa. Ponadto šŭrà w postaci, o jakiej wspomnieliśmy, nie niesie ograniczenia zasięgu działania najwyższej władzy ani ograniczenia jej kompetencji”, ${ }^{, 4}$.

Hayr ad-Dīn nadał ahl al-hall wa-ăl- 'aqd aktualne znaczenie: „Europejczycy ustanowili parlamenty i dali wolność prasie. W krajach muzułmańskich królowie czują respekt wobec tych, których zadaniem jest zmiana tego, co naganne, tak jak królowie europejscy czują respekt wobec parlamentów i opinii publicznej oraz wolności prasy, będących i ch pochodną. Cel obu instytucji był taki sam, a mianowicie ihtisāb, czyli służba państwu poprzez pilnowanie, aby było ono sprawiedliwe, nawet jeżeli ich drogi dochodzenia do tego celu różniły się", ${ }^{\circledR 5}$. W ten sposób Hayr ad-Dīn identyfikuje ahl al-ḥall wa-ăl-'aqd z parlamentami europejskimi: „Ci ludzie są nazywani przez Europejczyków delegatami do Rady Reprezentantów, a przez nas ahl al-hall wa-ăl-'aqd, nawet jeżeli nie są wybierani przez ludność" ${ }^{86}$. Jeśli chodzi o kompetencje tego organu nadaje mu jednak nowe funkcje i cele, bowiem w ich zakres wchodzi nadzór nad działaniami kalifa i ministrów oraz urzędników, a także głosowanie nad budżetem, podczas gdy w tradycyjnej teorii rola decydentów ograniczała się do wybierania i odwoływania władcy społeczności muzułmańskiej, co nie znajdywało jednak odzwierciedlenia w praktyce.

W ujęciu Hayr ad-Dīna ministerstwa mają charakter pełnomocnictw, a nie organów wykonawczych, jak miało to miejsce w przeszłości muzułmańskiej, a obecnie w Europie. W zakres obowiązków ministrów

\footnotetext{
Ibidem, s. 112.

Ibidem, s, 109.

Ibidem, s. 115; M. Mazālī, op. cit., s. 106.

Hayr ad-Dīn At-Tūnusī , op. cit., s. 108.

Ibidem, s. 192.
} 
wchodzi wybór urzędników i asystentów za zgodą kalifa albo króla, a podstawą dokonywania tegoż wyboru jest zasada przydziału stanowisk w oparciu o odpowiednie kwalifikacje. Koncepcja reformy systemu władzy wskazuje wyraźnie, iż Hayr ad-Dīn opowiada się za władzą zdecentralizowaną i systemem przedstawicielskim, wskazując na nieuniknioną porażkę centralnej władzy absolutnej. Jednocześnie podkreśla odpowiedzialność za postępowanie (tașarruf) jaka spoczywa na wszystkich, którzy zarządzają państwem, od urzędników począwszy, przez ministrów po władców, a u podstaw tej odpowiedzialności leży zasada ị̂tisābu ściśle związana z prawem muzułmańskim. Jest to bowiem jedna z doktryn islamu oparta na „nakazywaniu tego, co jest dobre i zakazywaniu tego, co jest złe” (al-amr bi-ăl-ma'rūf wa-ăn-nahy 'an ăl-munkar) ${ }^{87}$. Autor Najprostszej drogi... pragnął przywrócić zasadę ihtisābu, oddając funkcję „nakazywania tego, co jest dobre i zakazywaniu tego, co jest złe" ahl al-hall wa-ăl-aqd, tak, by stanowił organ doradczy władcy, a zarazem organ nadzoru w stosunku do działalności ministrów i urzędników oraz w stosunku do prawa i jego zgodności $\mathrm{z}$ šarīa.

Idee Hayr ad-Dīna dotyczące państwa w dużej mierze nie były nowe, można je swobodnie odnieść do pism XVIII-wiecznych europejskich myślicieli politycznych, zwłaszcza Charles’a Montesquieu - Monteskiusza, bowiem podobnie jak on kładzie nacisk na wolność jednostki w państwie i jest przekonany o możliwości prawidłowej organizacji państwa w oparciu o podział władzy. Innym źródłem jego koncepcji była faktyczna organizacja XIX-wiecznych państw europejskich, która generalnie stanowiła odbicie teorii Monteskiusza. Indywidualność tunezyjskiego reformatora i wyraźny charakter jego poglądów znalazły swoje odzwierciedlenie w sposobie, w jaki usiłował zidentyfikować zapożyczone idee z arabsko-muzułmańską teorią i praktyką polityczną i dostosować je do wymogów epoki. Aby pogodzić tradycję ze współczesną zachodnią myślą polityczną i ideami takimi jak podział władzy czy system kontroli, zmuszony był przeprowadzić radykalną reinterpretację tejże teorii i praktyki.

87 Nakaz ten wielokrotnie pojawia się w Koranie, np. wers 104, sura III Rodzina Imrana: „Nakazuje to, co jest uznane i zakazuje tego, co jest naganne"; wers 110, sura III Rodzina Imrana: „Wy nakazujecie to, co jest uznane, a zakazujecie tego, co jest naganne”; wers 157, sura VII Wzniesione krawędzie: „On im nakazuje to, co jest słuszne, a zakazuje tego, co niesłuszne” czy wers 71, sura IX Skrucha: „Oni nakazują sobie to, co uznane, a zakazują sobie tego, co naganne". Patrz: Koran, przekład J. Bielawski, PIW, Warszawa 1986. 
Koncepcje reformatorskie Hayr ad-Dīna nie odegrały większej roli poza Tunezją, ponieważ nie włączył się on w główny nurt reformizmu, który w XIX wieku skupiał się w Turcji osmańskiej, Egipcie i Indiach, jednak Najprostsza droga do poznania sytuacji w królestwach, stanowiąca kwintesencję jego myśli, której nadał kształt reform, uważana jest za jedno z najwybitniejszych dziewiętnastowiecznych dzieł arabskich w dziedzinie polityki i sztandarowe dzieło arabskiego odrodzenia.

M A G D A LENA LEWICKA 


\section{Abstract}

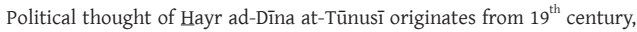
marked by the confrontation between developed and growing in power West and stagnating and yielding to European power Muslim and Arabic world. The necessity of this confrontation and deep awareness of the impotence of the Muslim society in the view of western supremacy and dominance became the cornerstones of all the future Arabic political ideas and the driving force to find the way to regain former power and strength, which have always been present in the Muslim philosophy of life. The Tunisian reformer was looking for such a way by attempting to answer the basic question bothering the citizens of Muslim and Arabic world - what are the reasons of its fall and underdevelopment and the basis of European supremacy, with consideration of despotic government, anachronistic social structures, lack of modern educational system and other issues, but most of all - crystallization of the ideas and reflections on the relationship between traditions and modernity, modern model of the state, society and politics. Hence the deliberations on the designand character of the relationship with the west, on full or partial reception of the European model of government, assumption of the attitude towards current political system and necessity of its reforming or reshaping, democracy and authoritarianism, the range of civil rights and subjection of the citizen towards the state. His views on the state and society were not a simple reflection of the ideas from abroad, nor the repetition of traditional, religious philosophy of life, but rather an attempt of working out a compromise between the European models and šari ${ }^{\circ}$ and embedding them in Muslim tradition in order to accommodate with Islam and its political theory. At the basis of this method there is the necessity to prove that firstly - European knowledge and science had belonged to Muslim world before they were intercepted by the West, and secondly - there is no contradiction between faith and modernity. The admiration of the author of The Simplest Way for European views on the government, society, legal, political and social systems was free from the implication of surrendering the Muslim traditions, or indifference towards them. Contrary - the basis of this admiration was the conviction that social and political thought of Islam has always been proclaiming the ideas which became the core of the European thought of enlightenment. Political and social doctrine of Hayr ad-Din was based on the ideas of the French Revolution and the rule of using the privileges of political and personal freedom, and that the mechanisms regulating the relationships between the government and society should be based on the respect of law. The reformation of Hayr adDinn is a compromise between two cultures - Islam and western civilizations. The meaning of his reformation program and his political thoughts made him the father of Tunisian revival and Aqwam al-masālik fì ma'rifat ahwāl al-mamālik one of the most distinguished Arabic works of $19^{\text {th }}$ century and leading manuscript of the Arabic revival. 